
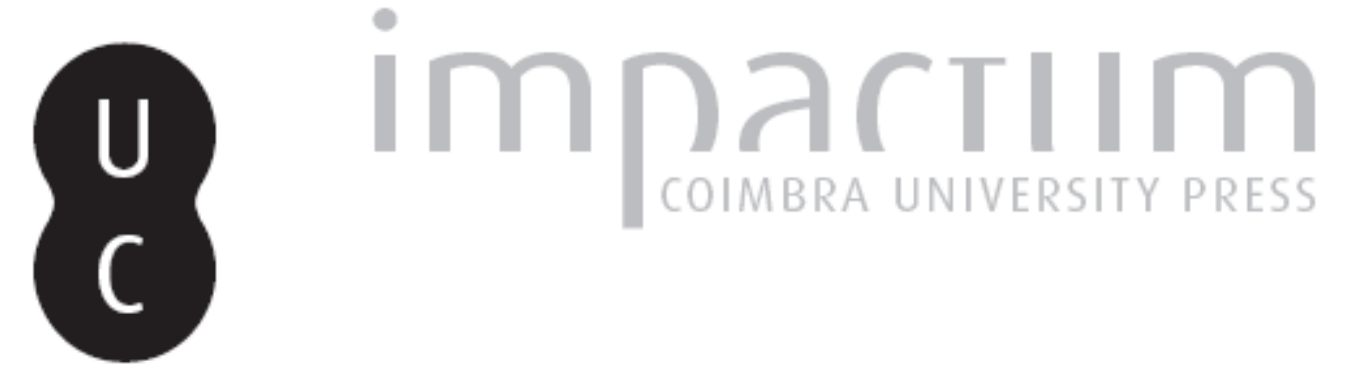

Urban environmental sustainability: implementing local agenda 21 in Manchester

Autor(es): Douglas, lan

Publicado por: Associação Portuguesa de Riscos, Prevenção e Segurança

URL persistente:

URI:http://hdl.handle.net/10316.2/40142

DOI:

DOI:https://doi.org/10.14195/1647-7723_4_1

Accessed : $\quad$ 26-Apr-2023 14:48:51

A navegação consulta e descarregamento dos títulos inseridos nas Bibliotecas Digitais UC Digitalis, UC Pombalina e UC Impactum, pressupõem a aceitação plena e sem reservas dos Termos e Condições de Uso destas Bibliotecas Digitais, disponíveis em https://digitalis.uc.pt/pt-pt/termos.

Conforme exposto nos referidos Termos e Condições de Uso, o descarregamento de títulos de acesso restrito requer uma licença válida de autorização devendo o utilizador aceder ao(s) documento(s) a partir de um endereço de IP da instituição detentora da supramencionada licença.

Ao utilizador é apenas permitido o descarregamento para uso pessoal, pelo que o emprego do(s) título(s) descarregado(s) para outro fim, designadamente comercial, carece de autorização do respetivo autor ou editor da obra.

Na medida em que todas as obras da UC Digitalis se encontram protegidas pelo Código do Direito de Autor e Direitos Conexos e demais legislação aplicável, toda a cópia, parcial ou total, deste documento, nos casos em que é legalmente admitida, deverá conter ou fazer-se acompanhar por este aviso.

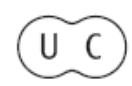




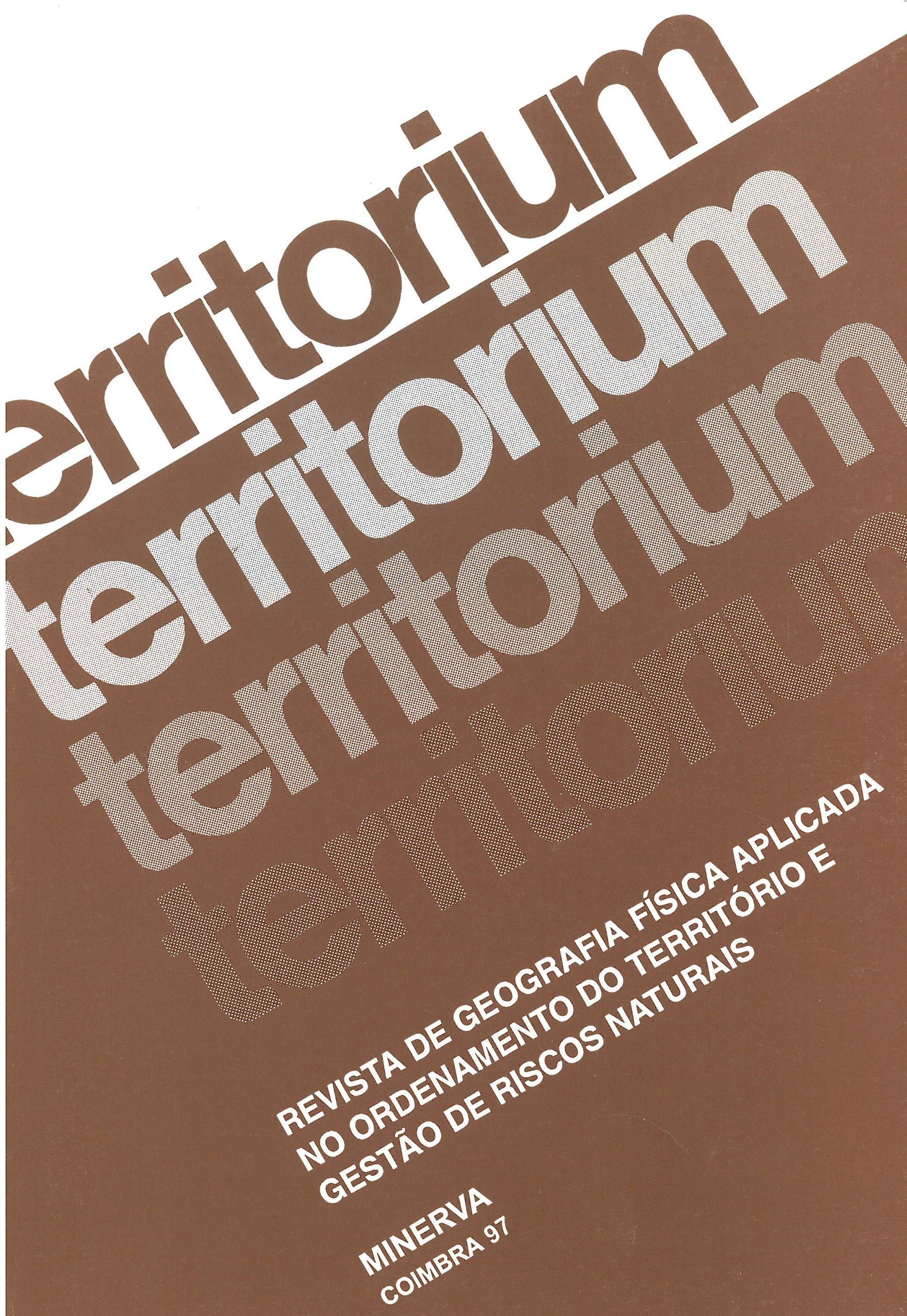




\title{
Urban environmental sustainability: implementing local agenda 21 in Manchester
}

\author{
Ian Douglas*
}

\begin{abstract}
Resumo:
Neste artigo examina-se o modo como a "Local Agenda 21 " tem vindo a ser implementada no Reino Unido e como ela envolve muitos aspectos da Geografia Física. A cidade de Manchester é apresentada aqui como um caso especial de estudo do processo de desenvolvimento da Agenda.

Palavras chave:

"Local Agenda 21", sustentabilidade do ambiente urbano, Manchester.
\end{abstract}

Résumé:

En cet article l'auteur examine le développement de la "Local Agenda 21" au Royaume Uni en montrant qu'il a fallut faire appel à beaucoup d'aspects de la Géographie Physique. La ville de Manchester a été prise comme cas d'étude dans le cadre du travail de la "Local Agenda 21".

Mots clés:

"Local Agenda 21", soutenabilité de l'environnement urbain, Manchester.

\begin{abstract}
:
This paper examines how Local Agenda 21 is being developed in the United Kingdom and how it envolves many aspects of Physical Geography. The Local Agenda 21 process in the City of Manchester is used as a special case study.

Key words:

Local Agenda 21, urban environmental sustainability, Manchester.
\end{abstract}

\section{Introduction}

Sustainable development as a concept affecting the thinking of the governments and peoples of the world really dates from the 1972 Stockholm Conference on the Human Environment. Thinking about environment cities at the international level comes from the same period, especially through the Project 11 (Urban Ecology) of the UNESCO Man and the Biosphere Programme. Initiatives such as the studies of urban metabolism and ecology in Hong Kong, Lae (Papua New Guinea) and Rome, brought home the dependence of cities on other environments and quantified just how cities modify the natural circulations of air, water and materials. These impacts have been

\footnotetext{
* Professor of Physical Geography, University of Manchester, and Chairman Manchester Local Agenda 21 Forum.
}

recently characterised by William REES (1992) as the ecological footprints of cities. An individual city relies on a collection of scattered support areas and creates a demand for changes in land-use that involve a quantity of land far exceeding that occupied by the city itself. The total area of land required to sustain an urban region (its ecological footprint) is typically at least an order of magnitude greater than that contained within municipal boundaries of the associated built-up are. The extra-urban landform modification (the geomorphological footprint) includes all the quarries, sand and gravel pits and mines supplying urban raw materials, together with all landfill, land reclamation and other waste disposal sites and the soil erosion involves in urban food production. Under Canadian living patterns (REES, 1992), the per capita land requirements for urban people are: 
- for food production

1.9 ha

- for timber and fossil fuel

3.5 ha (includes

forest to absorb $\mathrm{CO}_{2}$ )

- for raw material and waste 0.1 ha

The ecological footprints of cities include the geological transformations, in terms of rock removal and additions to the sedimentary record. The greatest single feat of denudation prompted by the needs of international trading cities was probably the excavation of the Panama Canal where $153 \mathrm{M} \mathrm{m}^{3}$ of mainly hard rock were removed. The Manchester Ship Canal involved the excavation of $40.9 \mathrm{M} \mathrm{m}^{3}$ of mainly unconsolidated material (SHERLOCK, 1931).

The United Nations set up the World Commission on Environment and Development in 1983 and its report Our Common Future (World Commission on Environment and Development, 1987) called on the General Assembly to establish a UN Programme of Action on Sustainable Development. This led to the UN Conference on Environment and Development (UNCED), known also as the Earth Summit or Rio 92. The major outcomes of the Earth Summit were the Climate Change Convention, the Biodiversity Convention, the statement on Forest Principles, the 27 principles for sustainability in the Rio Declaration (or Earth Charter) and Agenda 21. Although these important documents were signed, the outcomes fell short of many people's expectations or were weakened by compromise. The failure to make many agreements reflects the many economic and political questions underlying any transition to sustainable development (WHITNEY, 1994). This same trend of conflicting political, economic and social interests affects to work towards making cities more sustainable at the local level. This paper examines how Local Agenda 21 is being developed in the UK and how it involves many aspects of physical geography. The Local Agenda 21 process in the City of Manchester is used as a special case study.

\section{Physical Geography and Sustainability}

Achieving sustainability requires changes in the way natural environmental flows are modified to meet the needs of people in cities. Cities have dual energy, water and materials circulation systems. The climate of cities is modified by the physical character of the city and by the heat created by artificial energy consumption. Urban areas modify runoff to rivers, but also create artificial water supply and waste water disposal systems. Cities bring in huge quantities of mineral and biological materials to support their activities, and expel large quantities of waste, often creating artificial landforms in the way waste dumps become large hills, such as the notorious dumps around Istanbul in Turkey and near La Coruña, Spain. Well designed "land raise" mounds are to be found around Greater Manchester.

In these circumstances, urbanisation can be seen as creating a modified climate, hydrological cycle, geomorphic features and ecological environment. Pushed to the extreme, such modifications create environmental instability, for example when urban runoff creates downstream flooding or a land raise waste mound collapses and slides disastrously into neighbouring settlements. Sustainability implies reducing the scale of these transformations of the physiographic environment. Sustainability, in European countries, for most people, involves consuming less: reducing the magnitudes of energy, water and materials used and thus of the quantities of waste and contaminants generated. It also involves re-using materials and land: particularly regenerating the "brown lands", the derelict and abandoned industrial and mining land.

Studies of urban climate, air pollution, urban drainage and river pollution, urban geomorphology and ground stability and urban biogeography and soil formation all contribute to the scientific knowledge needed to develop strategies for more sustainable cities. The use of trees to modify the urban climate, absorb some locally generated greenhouse gases and reduce noise involves a whole series of environmental investigations of the type carried out by physical geographers. Modification of urban drainage by having porous pavements for roads and car parks, and by creating grassed waterways to cope with local runoff applies hydrology and fluvial geomorphology to urban sustainability.

Physical geographers, like others scientists, have to be prepared todevelop rigorous predictive techniques than can be used in forecasting the outcomes of different strategies for a more sustainable future. The ability to model and predict requires good field monitoring and computational skills, neither of which can be neglected in training future generations of physical geographers.

However it is not enough simply to do the good science. The outcomes of investigations have to be applied and incorporated into the planning and local agenda 21 processes. The significance and pratical value of the science has to be communicated to decision makers and all groups, or stakeholders involved in Local Agenda 21. Some physical 
geographers will need to become advocates for the policies that their science suggests are necessary for the sustainability of cities. Science, its application, and action for good policies are all needed.

\section{Local Agenda 21}

Chapter 28 of Agenda 21, entitled "Local authorities in support of agenda 21 " calls on local authorities to develop action plans for sustainable development at the local level. Paragraph 28.1 reads:

Because many of the problems and solutions being addressed by Agenda 21 have their roots in local activities, the participation and co-operation of local authorities will be a determining factor in fulfilling its objectives. Local authorities construct, operate and maintain economic, social and environmental infrastructure, oversee planning processes, establish local environmental policies and regulations, and assist in implementing national and sub-national environmental policies. As the level of governance closest to the people, they play a vital role in educating, mobilising and responding to the public to promote sustainable development.

Paragraph 28.2 sets an objective that by 1996 most local authorities in each country should have a consultative process with their populations and achieved a consensus on a local agenda 21 for the community. The next paragraph proposes that each authority should enter a dialogue with its citizens, local organisations and private enterprises and adopt a local Agenda 21.

The International Council for Local Environmental Initiatives (ICLEI), whose members are local governments, including Glasgow and Leicester among its Founder Members, has established the Local Agenda 21 Initiative to provide a common vehicle for local governments to strengthen local environmental planning and, thereby, to aid in the implementation of Agenda 21.

ICLEI's Local Agenda 21 Initiative has 3 main components:

- Local campaigns

- National Association campaigns

- The Local Agenda 21 Model Program are:

The basic elements of a local agenda 21 campaigns

- Community Consultation Processes sustainable development requires more equitable and efficient uses of resources. Achieving this demands multi-disciplinary input at the participation of every sector: individuals, households, community based organisations, business and government. These have to be consulted through public meetings, community forums, and the establishment of sustainable development councils or roundtables.

- Sustainable Development Auditing

- Target-setting

target will address quality of life, environmental quality, resource consumption and human development.

- Development and use of indicators

indicators should assist authorities ant their communities in monitoring their progress towards sustainable development, enabling them to compare their achievements over time.

In Britain, finding ways of translating sustainability into landuse and development decisions both in plan formulation and development control is seen as a major challenge for local planners. While in principle planning can be used to further sustainability objectives, in practice it is not always clear how the development process can be used to promote sustainability. The Department of Environment has issued planning guidance notes which exhort the adoption of, but do not always adequately explain how to achieve greater sustainability (WHITNEY, 1994). More seriously, while the Department of Environment urges planners to seek sustainability, the Department of Transport and of Trade and Industry pursue policies which expand road traffic and industrial impacts on the environment.

\section{Local Authority Promotion of Local Agenda 21 in Britain}

Many local authorities in Britain are attempting to find ways of planning for sustainability across many sectors and in their own activities. Lancashire, for example, has conducted it own environmental audit. Various interest groups or associations, including Friends of the Earth, the Association of Metropolitan Authorities and the local Government Management Board have set out and promoted good practice in promoting sustainability. In many ways, local authorities, stripped of many of their previous powers and responsibilities by the national government, have seen Local Agenda 21 as an opportunity to demonstrate their relevance in an issue of national and global significance which is also intimately connected to the wishes and well being of their local communities. Not surprisingly, therefore, the varied approaches by individual local authorities have produced the most innovative pilot schemes and initiatives to implement and manage sustainable development (WHITNEY, 1994). 
Much local experience has been brought together in the publications from Global Forum 1994 and trough the work of the BTEnvironment City Programme and of Environs in Leicester. In November 1990, the Kirkless Metropolitan District Council, which looks after an area of $250 \mathrm{Km}^{2}$ with 375000 inhabitants in West Yorkshire, adopted an environmental strategy with the following priorities:

- Energy: installation of a combined heat and power plant, working with energy-saving groups, monitoring energy consumption and setting up waste minimisation and recycling schemes.

- Transport: encouragement of less car use by staff, road safety schemes, improved and integrated public transport.

- Health: research into link between environment and health, pollution monitoring and local action supporting the WHO Health for All Initiative.

- Raising Environmental Awareness: public information and education with raised awareness of the changes needed for a more sustainable society.

In addition, the Kirkless Council has an ecological strategy and countryside management schemes with direct concerns for environmental management, especially the use of trees and managing open between urban areas. However, the real challenge, to Kirkless and other councils, is the actual implementation of strategies:

"Sustained local authority commitment, the ability to work corporately, build alliances and undertakings with external interests including the business community, the allocation of sufficient resources, the taking of controversial decisions - these and other factors will be crucial in "thinking globally and acting locally" (WHITNEY, 1994 p. 80).

Other local authorities have adopted different types of strategy: the basic differences lying in the degree to which a council directs or facilitates the creation of a Local Agenda 21 Statement or Strategy. In many instances the Council and its officers take the lead, doing all the investigation and producing the document for discussion the community.

Elsewhere the Council gets the Community to do the thinking and create the Statement. In both ways of operating, the type of statement which emerges depends on the people involved and their perception of the city and its problems.

\section{The Leicester Environment City Experience}

Leicester, a city of 280000 people in the Midlands of England, approached sustainability targets through the Leicester Environment City Trust which has a Board of Directors comprised of senior representatives from key organisations in the public, private, academic and voluntary sectors with (numerically) equal representation from each. This trust was effective in achieving partnerships between the city and other organisations and its independence gave greater freedom of action.

Specialist working groups were established to deal with:

- Built environment

- Energy

- Economy and work

- Food and Agriculture

- Natural Environment

- Transport

- Social Environment

- Waste and Pollution

Typically, each group comprised 8 to 20 members and initially met monthly. This involved a total of over 150 people attending working groups discussions. Much of the work of consulting the community and ensuring continuing public commitment has been led by Environs, an environmental business funded by the City Council, the World Wide Fund for Nature (WWF) and the Leicestershire County Council. Environs is now a major initiator and facilitator of local environmental and sustainability programmes throughout Europe with contacts further afield.

\section{The Leeds Environment City Experience}

Leeds City Council set up a series of Environment City Sustainability Working Groups and a steering forum bringing together representatives of the Council, of business groups and of voluntary organisations. It has established the Leeds Environmental Business Forum consisting of over 140 companies with responsibility for initiatives including:

- advice on environmental audit

- environmental reviews

- production of good practice guides

The Leeds Environmental Action Forum links 120 voluntary and community based organisations and individuals. Its main activity is networking and keeping the groups in touch. Specialist working groups were set up on the basis of need. If there was a specific task to be done, a group could be established.

\section{Local Agenda 21 in Manchester}

Manchester city Council's principles for action towards Local Agenda 21 acknowledge: 
- That sustainability is about the balance between environmental, economic, social and community concerns.

- That the Council's work towards sustainability should be related to its broad policies and aspirations for the City, some, such as re-populating the inner city being directly in accord with sustainability goals, but some of which may fit less well with Local Agenda 21 ideals.

- That the Council should be seen to be doing things itself, demonstrating to the outside world that it is taking sustainability seriously. It felt that it could not offer the leadership to the rest of the community in the Local Agenda 21 process without behaving more sustainable itself.

- That the absence of a State of the Environment report, or its equivalent, should not be seen as a barrier to action, but that the need for baseline information would have to be addresses in the Local Agenda 21 process.

\section{The City of Manchester Local Agenda 21 Forum}

After the 1994 Global Forum in Manchester at which cities from around the world compared their progress towards sustainability, Manchester City Council called together representatives from different sectors of the city community to discuss how to make progress towards Local Agenda 21. A strong lead was given by the Director of Planning, Ted Kitchen, whose department had established a professional sustainability group. The Manchester Local Agenda 21 Forum then set up comprises 4 representatives from each of 12 sectors of the City's communities and activities. Of the membership of 50, 5 are City Councillors, 4 represent local business and 4 local Universities and Colleges.

The Forum meets every two months and its Management Group meets in the other months. It is highly participatory, with everyone participating in discussion and many other people being involved in the working/action groups, which have drafted the parts of the statement concerned with the following themes:

- Health and a safer city

- Greening, Land-use and Open Space

- Transport

- Energy

- Economy and Work

- Education and Consultation

- Waste and Pollution

The action groups have each produced draft statements to go into the Local Agenda 21 statement for the city. Many public consultation and a large programme of interaction with young people have brought in many ideas and suggestions for the way in which Local Agenda 21 should proceed in Manchester. The draft statement was being edited in October 1996 for release to the citizens of Manchester for discussion and comment in January 1997.

The statement sets out principles and ideas for action, but as a document of only 40 pages, it will not be able to synthesise either the science of the detailed practical action necessary if Manchester is to become more sustainable. Nor does it set out the ways in which the city's major employers, the City Council itself, the hospitals and the Universities, together with a few major businesses, are going to have to blend their own environmental policies with those of the Local Agenda 21 statement. Much of the necessary work is already being done by organisations like Groundwork, the Manchester Wildlife Trust, the City Council itself and by school and community groups. Local Agenda 21 is thus contributing to the beginning of a co-ordination, public information and involvement programme which will prepare and encourage Manchester to be more sustainable. However, that goal will only be achieved if people and organisations change their behaviour. The biggest hurdle at the end of 1996 remains making people aware of what sustainability is and what Local Agenda 21 seeks to do.

\section{Conclusions}

- Local Agenda 21 provides many opportunities for building the environmental understanding gained from physical geography into local sustainability strategies.

- The complex environmental interactions, familiar to physical geographers, often cut across the strategies proposed by different working groups in the local agenda 21 process.

- The consultation process in local agenda 21 is a major listening and learning process in which "scientific knowledge" plays only a small part.

- Consultation can provide a platform for special interest groups with narrow viewpoints, but if successful ensures that the broad view of community needs and aspirations is understood by all.

- Making the Local Agenda 21 process independent of the Local Authority can improve the participation of all sectors of the community.

- Local Agenda 21 is above all about participation and must involve effective communication of ideas.

- Urban sustainability must address the magnitude of the urban footprint on other ecosystems: new urban energy, hydrological and materials cycles and flows are needed. 


\section{REFERENCES}

REES, W.E.(1992) - "Ecological footprints and appropriated carrying capacity: what urban economics leaves out". Environment and Urbanisation, 4, p. 121-130.

SHERLOCK, R.L. (1931) - Man's influence on the earth, Oxford University Press, Oxford.

WHITNEY, D. (1994) - "From the global to the local: Issues of policy implementation in sustainable development". In
WILliaMS, C.C. and HAUGHTON G. (eds.) Perspectives towards sustainable environmental development, Avebury, Aldershot, p. 65-82.

WORLD COMMISSION ONENVIRONMENT AND DEVELOPMENT (1987) - Our Common Future, Oxford University Press, Oxford. 